\title{
Bedside manner
}

Then there came a time when my body was set free by the lost memory

of my mother's loving eyes, my body set free to glide high riding impossibly silent flowing snowy slopes, my body set free to slide skinny slip-stream strokes through black and frigid crater lakes. Set free by a memory

or was it just

wishful thinking and not a lost memory at all, not lost like the riding and sliding.

So now here I lie convinced that I am ready to die, quivering butterfly wings pinned to crisp white linens. Here you come now to my side, a newborn's cry meeting mother eye-to-eye.

What is this gift that you ask of precious me like a beggar kneeling beside my bed holding my hand you say

I love you

and I will stay here with you.

Michael J. Passmore

Correspondence to Geriatric Psychiatry, University of British Columbia, c/o Mount St. Joseph Hospital, 3080 Prince Edward St, Vancouver, BC, V5T 3N4, Canada; mpassmore@providencehealth.bc.ca

Competing interests None

Provenance and peer review Not commissioned; internally peer reviewed.

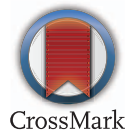

To cite Passmore MJ. Med Humanit 2017:43:e26.

Published Online First 27 April 2017

Med Humanit 2017;43:e26. doi:10.1136/medhum-2017-011232 